\title{
Study on the Role of Cultural and Creative Industries on the Development of Contemporary Design
}

\author{
Wei $\mathrm{Bi}^{1}$ \\ ${ }^{1}$ Tung-Fang Design Institute, Kaohsiung, Taiwan, 000800
}

KEYWORDS: The Development of Design; Cultural and Creative Industry

\begin{abstract}
As today's creative industry buzzword frequently appears on various media, because of its excellent performance in economic growth and expansion of employment and other aspects of attention of the world, countries have begun to develop creative industry and its research, from theory into practice industry, form a creative industry boom "creative industries vitality and rapid development momentum for us to declare a coming era of creative industries, creative industries has become an indisputable social reality" at the same time, the production of industrial design in the economy great role also attracted more and more attention, more and explore its development strategy in the background of the creative industries in order to make the role of industrial design has become a very urgent task. "However, the current study focuses on the creative industries at home and abroad economic and cultural aspects of the creative industries and the relationship between industrial design and creative industries, how to guide the development of industrial design is still no comprehensive detail.
\end{abstract}

\section{Introduction}

Cultural and creative industries that are dependent on the wisdom, talent and creativity, by means of a high-tech integration of cultural resources, the creation and promotion, through the development and application of knowledge to produce high value-added products, with the creation of economic value and employment potential industrial, cultural and creative industries comprising UNESCO considered cultural products, the three elements of cultural services and intelligent property rights. Any kind of cultural and creative activities, to be in a certain cultural background, but the idea is not a simple copy of culture, but on people's knowledge and creativity by using technology to further enhance the traditional cultural resources. Cultural and creative industries, emerging industries belong to the intellectual and creative, has the following characteristics: cultural and creative industries have a high informative features. Cultural and creative industries are generally related cultural products and cultural products, innovative products, human knowledge, wisdom utilization in the cultural industry. Cultural and creative industries and information technology, communication technology, science and technology are closely related, showing high intellectual characteristics. Cultural and creative industries are with high added value features. Cultural and creative industries is the process of cultural industries and related industries, technological and cultural innovation and product development and promotion of the industry value chain, comprehensive operation, impact on other industries, and promote each other, resulting in a high value-added industry, economic or cultural value. Cultural and creative industries are with a high integration of features. Cultural and creative industries as an emerging industry, it is the merging of 
politics, economy, culture, science and technology industry, a high degree of fusion, faster and better economic and social development of superior environment. Development of cultural and creative industries and related industries is to promote political and economic development of society, while the spread of culture play a positive role.

\section{Culture of Art \& Design Industry Status and Its Analysis}

The cultural industry has become part of the economic development of the socialist political culture has become an important way people's spiritual and cultural needs, the proportion of cultural industries in the national economy is also rising and improve. National "Eleventh Five-Year Plan" has put the cultural industry as an important strategy for national economic development, the central and local government has issued a series of encouraging cultural industry development policies and measures. Local governments and cities have come to realize the importance of development of cultural industries. Provinces, municipalities proposed proposed the building of cultural province, provincial goal of strong cultural, national cultural industry revitalization plan for the development of cultural industries have a significant role in promoting the plan put forward at this stage will strengthen the cultural industry base layout and overall planning, adhere to standards, highlighting features, increase the level, and promote the rational allocation of resources and industrial division of labor. Some radiation-building the country's regional and cultural products logistics center, construction of a number of cultural and creative, video production, publishing, printing and copying, performing arts and entertainment and animation and other industrial demonstration bases, to support and accelerate the development of cultural industry group with regional and national characteristics. We believe that cultural industries in the State, local governments and related practitioners work together to develop cultural and creative industries will promote the political, economic and cultural development, while driving to drive the development of contemporary art and design, the early realization of the great rejuvenation of the Chinese nation.

\section{The Affect of Contemporary Art on Design}

Popular culture that is relative to the edge of the culture, that is the mainstream of popular culture, it is easy to accept the culture, mass culture is mainly under the guidance of the occurrence of the mass media A media culture development and change, entertaining, commodity, epidemic , popular features. Extensive use of the mass media also spread popular culture has played a catalytic role in contemporary society, artwork by previous royal proprietary become today everyone can enjoy, everyone can consume art, everyone can enjoy, experience and feelings of art outside the United States and content, a variety of popular music, popular entertainment, etc. on popular culture has, at sub-culture the concept of shelter, he put art, literature, music, fashion and even attitudes are stirred in together, and put them on the same plane were analyzed. Contemporary art and design reflect the popular culture at Volkswagen, randomness and civilians features.

Consumer culture is the experience of a culture of consumption behavior of the consumer economy, including material consumer culture consumer culture, the spirit of consumer culture, is an important part of the social culture. Politics, economy, culture, way of life and the concept of life and so have an impact on consumer culture. China last three decades the rapid development of society, the moment has entered the era of mass consumption, mass consumption related to the political and economic and cultural fields, under the influence of consumer culture cultural industries of contemporary art and design background is reflected in: consumer culture gives artists 
all kinds of strange new visual experience, have an impact on artists, designers, art work, design work.

1913 Hungary Balazs film esthetician first proposed the concept of visual culture, visual culture that people can be perceived through the visual culture, visual culture is also gradually reflect cultural characteristics, aspects of contemporary culture increasingly inclined high visualization, our age is also an era of pictures, images and video are gradually replacing text, contemporary culture highly visual culture to bring a new experience. Transformation of contemporary culture is bound to affect the transformation of contemporary art and design, visual culture from the impact of two one variety of clothing exhibition, exhibition, art exhibition of contemporary fashion culture so that the current culture reflects a high degree of visual. Second, the economy is gradually coming eye the visual impact of the development trend of culture. Contemporary visual culture as a form of cultural influence on art and design is reflected in a high degree of visual art and design work. Mainly for visual and readable symbol, the body such as interactive media and performance art - space body language and artistic expression, construction and other figurative and spiritual world.

Marginal culture is always vulnerable, non-mainstream culture, people are keen to mainstream culture, while ignoring the value of the edge of Culture. Dunhuang culture is the culture of the edges on behalf of the arts, culture produced in China Dunhuang culture, Indian culture and West cross cultural area edge. Dunhuang art form and style of traditional art forms are compared to edge art form. American culture is distinctive edge culture illustration. American cultural integration of Europe, the Americas and the rest of the world culture, it is a multi-cultural and ethnic characteristics known to the world, through two world wars escalating American culture for the world of mainstream culture. Advantages edge of culture is that it is a wide range of cultural resources of organic components. Different mainstream culture caused a different edge culture. Edge culture at the edge of culture, marginal culture as part of the culture on the development of cultural and creative industries have a certain role in promoting and facilitating the cultural industry under the edge of the cultural influence gradually from the edge to the center of the industrial industry.

\section{Study the Contemporary Art and Design from the Cultural Phenomenon of Cultural Industries}

The rise and development of cultural and creative industries is the contemporary political, economic, cultural, scientific and technological development in the industry level of mutual embodied. With its unique form and development among other industries produce extensive and complex linkages greatly affect a country's economic, social and cultural development of a city or a region. Contemporary art and design as part of the cultural industry, the power of art and how it fits into the contemporary cultural industry complementary development of both, we need to think deeply and continue to study. Contemporary art and design in the cultural and creative industries and cultural background of possible future trends.

Cultural connotation of the art and design work has been accepted by the community and the public, in order to better and faster development must go down a road of industrialization and prosperity, the introduction of the concept of the soul in cultural industries, to optimize industrial development.

Creativity is the soul of art, creation and transformation of major cultural industry park, art industrial park at the same time, to propose appropriate core concepts for the urban, environmental economic and other factors, the city industrial park playing with the core concept of the city park. 
Looking between urban culture and creative industries is the core of the soul of the urban culture industry, namely contemporary art recycling industry on the basis of design culture, Cultural and creative industries and design of future models may take a Art - Creative - cultural industry chain the road of sustainable development.

Contemporary design of cultural industries under mainly in art and design, business design and social design in the form of three designs, three design influences in the cultural and creative industries reflect the following creative, industrial and cultural characteristics. Art and design to meet the man and nature, social relations in the traditional sense design, creative art-based design. Design business is operating for the purpose, to meet market demand, design, reflecting production, marketing, consumption and other economic characteristics of the design, operation design more reflects the characteristics of the design industry.

\section{Conclusion}

Culture and industry combines to form the cultural and creative industries, and promote economic development, but economic development, promote the development of contemporary art and design, contemporary art and design in the cultural and creative industries in this cultural context, how development is very important to with a new perspective on to understand, analyze and understand the current situation of contemporary art and design, and the possibility of future development. Multicultural involvement in the cultural and creative industries will affect the background of contemporary art and design diversity, richness of diversified pattern.

\section{Reference:}

[1] Florida, R. The Rise of Creative Class [M]. New York:. Basic 2002.

[2] Harald Bathelt. Toward a multidimensional conception of clusters. the case of the Leipzig media industry. Germany. Cultural Industries and the Production of Culture [M]. Roult edge, 2004.

[3] Matheson, B A Culture of creativity:.. Design education and the creative Industries Journal of Management Development.2006, v.25 (n.1): p.55-64.

[4j Frontier Economies. Comparative an analysis of the UK. Creative industries. United Kingdom.2006. 